\title{
Computational and experimental study for the desalination of petrochemical industrial effluents using direct contact membrane distillation
}

\author{
Muhammad S. Osman ${ }^{1}$. Vhahangwele Masindi ${ }^{1,2}$ (D) Adnan M. Abu-Mahfouz ${ }^{1,3}$
}

Received: 13 February 2018 / Accepted: 11 February 2019 / Published online: 22 February 2019

(c) The Author(s) 2019

\begin{abstract}
The petrochemical, mining and power industries have reacted to the recent South African water crisis by focussing on improved brine treatment for water and salt recovery with the aim of achieving zero liquid effluent discharge. The purpose of this novel study was to compare experimentally obtained results from the treatment of synthetic $\mathrm{NaCl}$ solutions and petrochemical industrial brines such as spent ion exchange regenerant brines and reverse osmosis (RO) brines to the classical well-known Knudsen diffusion, molecular diffusion and transition predictive models. The predictive models were numerically solved using a developed mathematical algorithm that was coded using MATLAB ${ }^{\circledR}$ software. The impact of experimentally varying the inlet feed temperature on process performance of the system is presented here and compared to simulated results. It was found that there was good agreement between the experimentally obtained results, for both the synthetic $\mathrm{NaCl}$ solution and the industrial brines. The mean average percentage error (MAPE) was found to be $7.9 \%$ for the synthetic $\mathrm{NaCl}$ solutions when compared to the Knudsen model. The Knudsen/molecular diffusion transition theoretical model best predicted the performance of the membrane for the industrial spent ion exchange regenerant brine with a mean absolute percentage error (MAPE) of 13.3\%. The Knudsen model best predicted the performance of the membrane (MAPE of $10.5 \%$ ) for the industrial RO brine. Overall, the models were able to successfully predict the water flux and can be used as potential process design tools.
\end{abstract}

Keywords Direct contact membrane distillation - Spent ion exchange regenerant $\cdot$ Reverse osmosis brines $\cdot$ Water recovery $\cdot$ Brine treatment

\begin{tabular}{|c|c|c|c|}
\hline \multicolumn{2}{|r|}{ List of symbols } & $C_{\mathrm{mp}}$ & Permeate side membrane concentration \\
\hline \multirow[t]{2}{*}{$B_{\mathrm{m}}$} & Thermally driven mass transfer coefficient & & $(\mathrm{mg} / \mathrm{l})$ \\
\hline & $\left(\mathrm{kg} / \mathrm{m}^{2} \mathrm{~s} \mathrm{~Pa}\right)$ & $C_{\mathrm{n}}$ & Permeate concentration $(\mathrm{mg} / \mathrm{l})$ \\
\hline$C_{\mathrm{f}}$ & Feed concentration $(\mathrm{mg} / \mathrm{l})$ & ${ }^{\mathrm{p}}$ & Diffusion coefficient $\left(\mathrm{ms}^{-2}\right)$ \\
\hline$C_{\mathrm{mf}}$ & Feed side membrane concentration $(\mathrm{mg} / \mathrm{l})$ & $h_{\mathrm{f}}$ & $\begin{array}{l}\text { Feed side heat transfer coefficient } \\
\left(\mathrm{W} \mathrm{m} \mathrm{m}^{-2} \mathrm{~K}^{-1}\right)\end{array}$ \\
\hline & & $h_{\mathrm{m}}$ & Membrane heat transfer coefficient \\
\hline$凶$ & Vhahangwele Masindi & & $\left(\mathrm{W} \mathrm{m}{ }^{-1} \mathrm{~K}^{-1}\right)$ \\
\hline & VMasindi@csir.co.za & $h_{\mathrm{p}}$ & Permeate heat transfer coefficient \\
\hline & Muhammad S. Osman & & $\left(\mathrm{W} \mathrm{m} \mathrm{m}^{-2} \mathrm{~K}^{-1}\right)$ \\
\hline & mosman@csir.co.za & $H_{\mathrm{v}}$ & Latent heat of vaporisation $\left(\mathrm{J} \mathrm{kg}^{-1}\right)$ \\
\hline 1 & $\begin{array}{l}\text { Council for Scientific and Industrial Research (CSIR), P.O. } \\
\text { Box 395, Pretoria 0001, South Africa }\end{array}$ & $\begin{array}{l}J \\
k_{\text {air }}\end{array}$ & $\begin{array}{l}\text { Water flux }\left(\mathrm{L} \mathrm{m}^{-2} \mathrm{~h}^{-1}\right) \\
\text { Thermal conductivity of the air }\left(\mathrm{W} \mathrm{m}^{-1} \mathrm{~K}^{-1}\right)\end{array}$ \\
\hline 2 & Department of Environmental Sciences, School & $k_{\mathrm{f}}$ & Mass transfer coefficient $\left(\mathrm{m} \mathrm{s}^{-1}\right)$ \\
\hline & $\begin{array}{l}\text { of Agriculture and Environmental Sciences, University } \\
\text { of South Africa (UNISA), P.O. Box 392, Florida 1710, }\end{array}$ & $k_{\mathrm{m}}$ & $\begin{array}{l}\text { Thermal conductivity of the membrane } \\
\left(\mathrm{W} \mathrm{m} \mathrm{m}^{-1} \mathrm{~K}^{-1}\right)\end{array}$ \\
\hline & South Africa & $k_{\mathrm{s}}$ & Thermal conductivity of the polymer mate- \\
\hline (a) & $\begin{array}{l}\text { Department of Electrical Engineering, Tshwane University } \\
\text { of Technology, Private Bag X680, Pretoria 0001, }\end{array}$ & $K_{\mathrm{n}}$ & $\begin{array}{l}\text { rial }\left(\mathrm{W} \mathrm{m}^{-1} \mathrm{~K}^{-1}\right) \\
\text { Knudsen number }(-)\end{array}$ \\
\hline
\end{tabular}




\begin{tabular}{|c|c|}
\hline$M$ & Molecular weight $\left(\mathrm{g} \mathrm{mol}^{-1}\right)$ \\
\hline$p$ & Vapour pressure $(\mathrm{Pa})$ \\
\hline$p_{\mathrm{mf}}$ & $\begin{array}{l}\text { Vapour pressure at the feed membrane inter- } \\
\text { face }(\mathrm{Pa})\end{array}$ \\
\hline$p_{\mathrm{mp}}$ & $\begin{array}{l}\text { Vapour pressure at the permeate membrane } \\
\text { interface }(\mathrm{Pa})\end{array}$ \\
\hline$P$ & Total pressure $(\mathrm{Pa})$ \\
\hline$P_{\mathrm{a}}$ & $\begin{array}{l}\text { Partial pressure of air in membrane pores } \\
(\mathrm{Pa})\end{array}$ \\
\hline$q_{\mathrm{f}}$ & Feed flow rate $\left(\mathrm{ml} \mathrm{min}^{-1}\right)$ \\
\hline$q_{\mathrm{p}}$ & Permeate flow rate $(\mathrm{ml} \mathrm{min}-1)$ \\
\hline$Q$ & Heat flux $\left(\mathrm{W} \mathrm{m}^{-2}\right)$ \\
\hline$Q_{\mathrm{f}}$ & Feed side convective heat flux $\left(\mathrm{W} \mathrm{m}^{-2}\right)$ \\
\hline$Q_{\mathrm{m}}$ & $\begin{array}{l}\text { Conductive heat flux through the membrane } \\
\left(\mathrm{W} \mathrm{m}^{-2}\right)\end{array}$ \\
\hline$Q_{\mathrm{p}}$ & Permeate side convective heat flux $\left(\mathrm{W} \mathrm{m}^{-2}\right)$ \\
\hline$R^{\mathrm{p}}$ & Universal gas constant $\left(\mathrm{J} \mathrm{mol}^{-1} \mathrm{~K}^{-1}\right)$ \\
\hline$T$ & Temperature $(\mathrm{K})$ \\
\hline$T_{\mathrm{f}}$ & Feed side inlet temperature $(\mathrm{K})$ \\
\hline$T_{\mathrm{m}}$ & $\begin{array}{l}\text { Average temperature across the membrane } \\
(\mathrm{K})\end{array}$ \\
\hline$T_{\mathrm{mf}}$ & Feed side membrane temperature $(\mathrm{K})$ \\
\hline$T_{\mathrm{mp}}$ & Permeate side membrane temperature $(\mathrm{K})$ \\
\hline$T_{\mathrm{p}}$ & Permeate temperature $(\mathrm{K})$ \\
\hline
\end{tabular}

Greek symbols

$\tau \quad$ Membrane tortuosity (-)

$\delta \quad$ Membrane thickness (m)

$\varepsilon \quad$ Membrane porosity (-)

$\rho \quad$ Density $\left(\mathrm{kg} \mathrm{m}^{-3}\right)$

\section{Abbreviations}

$\begin{array}{ll}\text { AGMD } & \text { Air gap membrane distillation } \\ \text { CSIR } & \text { Council for Scientific and Industrial Research } \\ \text { C\&PUW } & \text { Condensate and pickup water } \\ \text { DCMD } & \text { Direct contact membrane distillation } \\ \text { EDR } & \text { Electrodialysis reversal } \\ \text { FO } & \text { Forward osmosis } \\ \text { IX } & \text { Ion exchange } \\ \text { MAPE } & \text { Mean average percentage error } \\ \text { MD } & \text { Membrane distillation } \\ \text { RO } & \text { Reverse osmosis } \\ \text { SGMD } & \text { Sweeping gas membrane distillation } \\ \text { TDS } & \text { Total dissolved solids } \\ \text { TOC } & \text { Total organic carbon } \\ \text { VEDCMD } & \text { Vacuum-enhanced direct contact membrane } \\ & \text { distillation } \\ \text { VMD } & \text { Vacuum membrane distillation }\end{array}$

\section{Introduction}

Brine treatment and disposal pose serious challenges for industries particularly the petrochemical, mining and power industries. These industries utilise membrane desalination technologies such as reverse osmosis (RO), electrodialysis reversal (EDR) and ion exchange (IX) to treat their saline effluent (Alkhudhiri et al. 2012; AlHathal Al-Anezi et al. 2013; Abu-Zeid et al. 2015; Drioli et al. 2015; Bogler et al. 2017; Eykens et al. 2017; Thomas et al. 2017). During the treatment processes, large quantities of difficult to treat brines are generated, and for landlocked process plants, these brines are usually stored in evaporation ponds (Kaplan et al. 2017). Storage/disposal of brines in evaporative ponds runs the inherent risk of surface and underground water contamination, thus potentially violating stringent environmental regulations (Alshahri 2017; Hossack et al. 2017). As such, some of these industries often opt to treat the resultant brines using thermal distillation technologies such as evaporative crystallisers or film falling and forced circulation evaporators (Chang et al. 2012; Adham et al. 2013, Joe Patrick Gnanaraj et al. 2016). However, these membrane and distillation technologies have their fair share of problems ranging from fouling and scaling to being energy intensive and costly. Fouling and scaling often limits the efficiency and usefulness of these technologies (Alkhudhiri et al. 2012; Yang et al. 2013; Naidu et al. 2016). Evaporators are also prone to scaling which results in operational downtime (Bigham et al. 2015).

Ion exchange resins have also been used frequently in industry for wastewater treatment (Battaerd et al. 1973; Abdulgader et al. 2013). Documented studies reported that ion exchange technologies have the capability of treating fairly concentrated brackish water (Pless et al. 2006; Smith and Sengupta 2015). The advantages of ion exchange treatment is that high pumping pressures, extensive pretreatment or high thermal energy input is not required. However, the process is limited by the saturation of the resin which needs large volumes of acidic and/or basic solutions for their regeneration (Hendry 1982; Pless et al. 2006; Sarkar and SenGupta, 2007).

Membrane distillation (MD) is an upcoming hybrid technology that has the ability to treat brine effluent via the combination of desalination and distillation processes (AlHathal Al-Anezi et al. 2013; Pangarkar et al. 2013). When compared to well-known commercial membrane technologies such as RO, MD offers the following benefits (Tijing et al. 2014; Wang and Chung 2015; Thomas et al. 2017):

- Operation at lower temperatures and pressures than conventional distillation and membrane processes. 
- The use of polymeric membranes that have less demanding properties and are more resistant to scaling and fouling.

- High salt rejections of more than $99 \%$ can be achieved.

- Waste or solar energy can be potentially used to drive the process improving the economics of the process.

Previous studies have demonstrated that membrane distillation can be used for a variety of hybrid applications ranging from concentration fruit juices (Bagger-Jørgensen et al. 2011; Onsekizoglu Bagci 2015) to concentration aqueous solution (Bélafi-Bakó and Boór 2011). Zhao et al. (2013) have also proposed a hybrid system for treating human liquid waste. Recent MD research has been focused on understanding transport properties and phenomena as well as factors affecting membrane properties and developing improved membrane materials for use in future MD studies (Ashoor et al. 2016; Bogler et al. 2017). In recent times, MD has also being viewed as a potential technology for brine treatment (Ji et al. 2010; Soliman et al. 2017). Li et al. (2014) and Lee et al. (2015) successfully desalinated brine streams with a hybrid vacuum-enhanced direct contact membrane distillation (VEDCMD) and forward osmosis (FO) system. Kesieme and Aral (2015) propose the use of DCMD for water and acid recovery from acidic mine waste. Most of the research found in the literature provides concepts on MD applications and potential hybrid solutions for brine treatment (Xie et al. 2013; Chafidz et al. 2016). However, there appears to be few articles on the process design of MD systems (Chafidz et al. 2016). Gurreri et al. (2017) focus on the use of spacers for full-scale applications.

This paper focuses on investigating the use of well-known predictive models (Knudsen, molecular diffusion and transition) to supplement the process design aspect of DCMD systems. In order to achieve this objective, a custom-built DCMD system was constructed and experiments were conducted on synthetic $\mathrm{NaCl}$ solutions and industrial brines (acidic complex spent ion exchange regenerant brines and RO brines) resulting from the desalination of petrochemical operations. The results from the experimental runs were compared to the predictive models available in the literature. A mathematical algorithm was developed from the basic mass and energy balances that lead to a system of nonlinear equations which was solved using MATLAB ${ }^{\circledR}$ software. To the best of authors' knowledge, such a study has not been conducted before.

\section{The membrane distillation process: theory and modelling}

$\mathrm{MD}$ is a thermally driven process where a hydrophobic microporous membrane is used to separate aqueous hot feed solutions at different temperatures and compositions
(Lawson and Lloyd 1997; Luo and Lior 2016). The temperature and composition difference results in a vapour pressure difference across the membrane surface. Vapour molecules migrate from a high-vapour-pressure side through the pores of the membrane to the low-vapour-pressure side (Alkhudhiri et al. 2012; AlHathal Al-Anezi et al. 2013; Ashoor et al. 2016). There are four well-known membrane distillation configurations: direct contact membrane distillation (DCMD) (Ahmad et al. 2015), air gap membrane distillation (Guo et al. 2017), sweeping gas membrane distillation (SGMD) (Fatehi et al. 2017) and vacuum membrane distillation (VMD) (Abu-Zeid et al. 2015) as shown in Fig. 1.

DCMD is one of the simplest MD configurations and has been widely studied (Ashoor et al. 2016). In this configuration, a concentrated hot feed solution is in direct contact with one side of the membrane and a cold permeate is in direct contact with the opposite side of the membrane. The vapour molecules migrate through the membrane pores and condenses at the permeate side and is removed with the permeate (Burgoyne and Vahdati 2000; Khayet et al. 2005; Ashoor et al. 2016). AGMD is similar to DCMD; however, the permeate side is separated by an air gap (Guo et al. 2017). This results in an increase in mass and heat transfer. The product condenses against the cooling plate and is removed (Ashoor et al. 2016; Bogler et al. 2017). SGMD has a configuration similar to AGMD; however, an inert gas typically air is used to remove the vapour molecules. A condenser is used to condense the vapour molecules into condensate product. VMD is similar to SGMD; however, vacuum conditions are used in the process. Some of the advantages of DCMD are that it is simple in its design, no external equipment such as condensers is required and condensation of the permeate occurs inside the membrane module (El-Bourawi et al. 2006; Gullinkala et al. 2010; AlHathal Al-Anezi et al. 2013; Ashoor et al. 2016; Bogler et al. 2017; Eykens et al. 2017). DCMD is therefore investigated further in this study.

\section{Modelling the mass and heat transfer phenomena in DCMD}

Mass and heat transfer occurs simultaneously in the DCMD process. Mass migration of vapour molecules through the membrane typically occurs as a result of one of the following mass transfer mechanisms: Knudsen diffusion, Poiseuille flow (viscous flow), molecular diffusion, transition flow (which is a combined effect of Knudsen diffusion and molecular diffusion) and surface diffusion (Khayet et al. 2005; Ashoor et al. 2016, Kim et al. 2017). When the DCMD system is dominated by Knudsen flow, collisions frequently occur between the water vapour molecules and the pore wall. Poiseuille flow occurs when the water vapour molecules collide with each other and less frequently with the membrane. Molecular diffusion occurs 

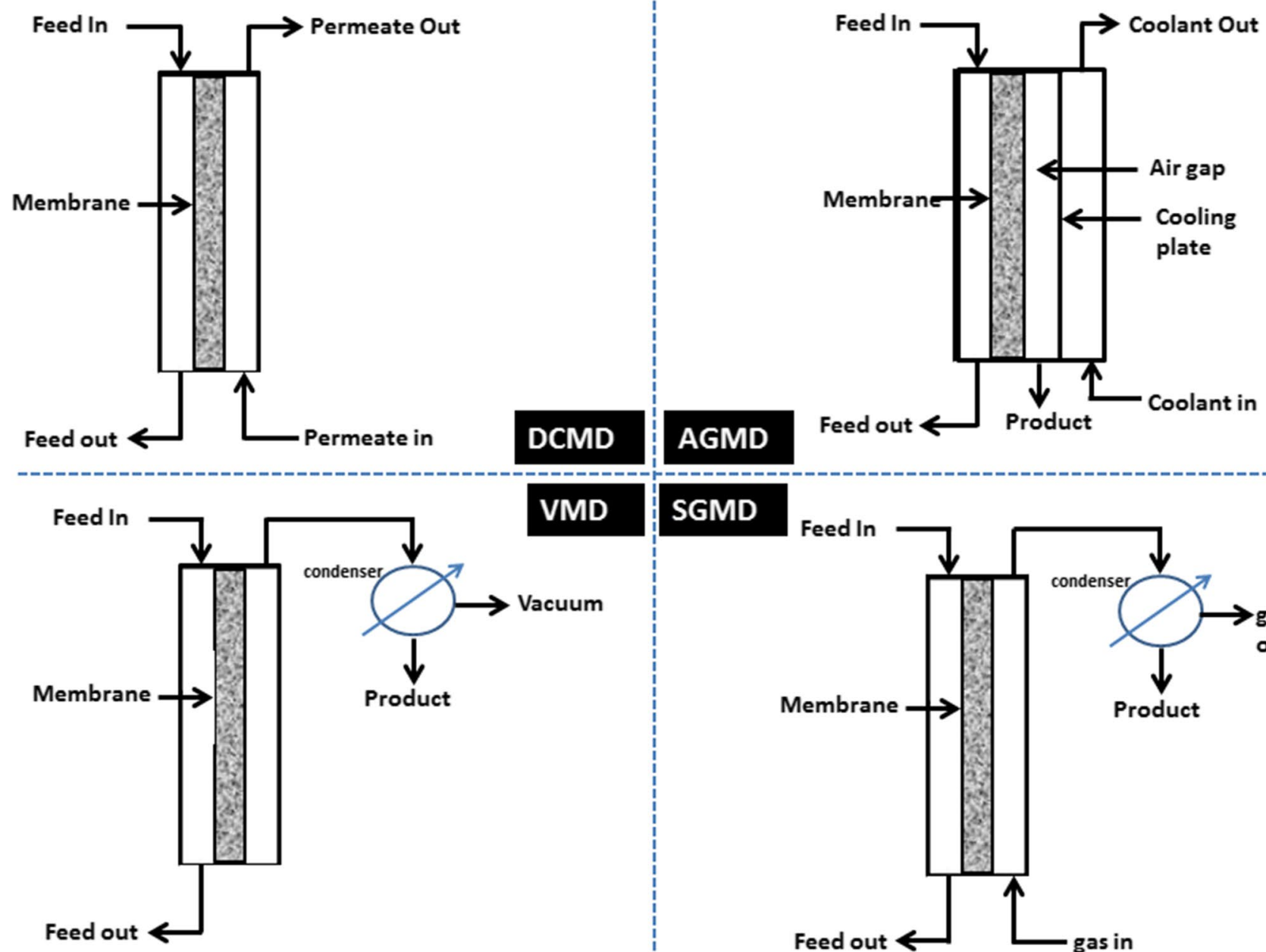

AGMD

Product

\section{SGMD}

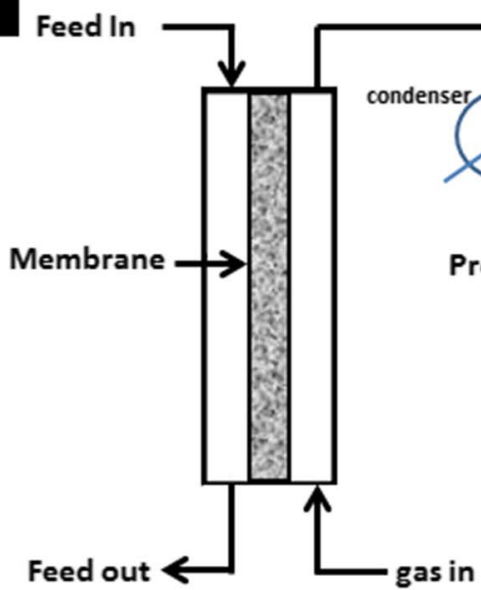

Fig. 1 Various MD configurations. (Adapted from (Khayet et al. 2003; Awad et al., 2013; Swaminathan et al. 2016))

when there are collisions between water molecules and the pore wall as well as collisions between water molecules and stagnant air molecules. Poiseuille flow and surface diffusion are usually rendered insignificant in DCMD modelling (Burgoyne and Vahdati 2000; Khayet et al. 2005; Ashoor et al. 2016). Figure 2 shows the temperature concentration and vapour pressure profiles in DCMD.

In Fig. 2, $p_{\mathrm{mf}}$ and $p_{\mathrm{mp}}$ are the feed side vapour pressure of the membrane and the permeate vapour pressure, respectively, and can be calculated from the Antoine equation and from Raoult's law (Phattaranawik et al. 2003; Mariah et al. 2006; Drioli et al. 2015). $T_{\mathrm{f}}$ is the feed side inlet temperature, $T_{\mathrm{mf}}$ is the feed side membrane temperature, $T_{\mathrm{mp}}$ is the permeate side membrane temperature and $T_{\mathrm{p}}$ is the permeate temperature. $C_{\mathrm{f}}, C_{\mathrm{mf}}, C_{\mathrm{mp}}$ and $C_{\mathrm{p}}$ are the feed side inlet concentration, the feed side membrane concentration, the permeate side membrane concentration and the permeate concentration, respectively. $J$ and $Q$ are the water flux and the heat flux, respectively.
The water flux through the membrane, $J$, can be calculated from the following expression (Gryta et al. 2006):

$J=B_{\mathrm{m}} \Delta p=B_{\mathrm{m}}\left(p_{\mathrm{mf}}-p_{\mathrm{mp}}\right)$

where $B_{\mathrm{m}}$ is the membrane coefficient and $\Delta p$ is the vapour pressure difference across the membrane. $B_{\mathrm{m}}$ is determined from the governing transport mechanism (Eqs. 2-4) which in turn is determined from the Knudsen number, $K_{\mathrm{n}}$ (Drioli et al. 2015). The Knudsen number, $K_{\mathrm{n}}$, is defined as the ratio between the mean free path of the water vapour molecules and the membrane pore diameter.

When $K_{n}>1$, the mass transfer of the vapour molecules is dominated by Knudsen diffusion and the water flux is calculated from Eq. (2):

Knudsen diffusion $\left(K_{\mathrm{n}}>1\right): B_{\mathrm{m}}=\frac{2 r \varepsilon}{3 \tau \delta}\left(\frac{8 M}{\pi R T_{\mathrm{m}}}\right)^{0.5}$ 


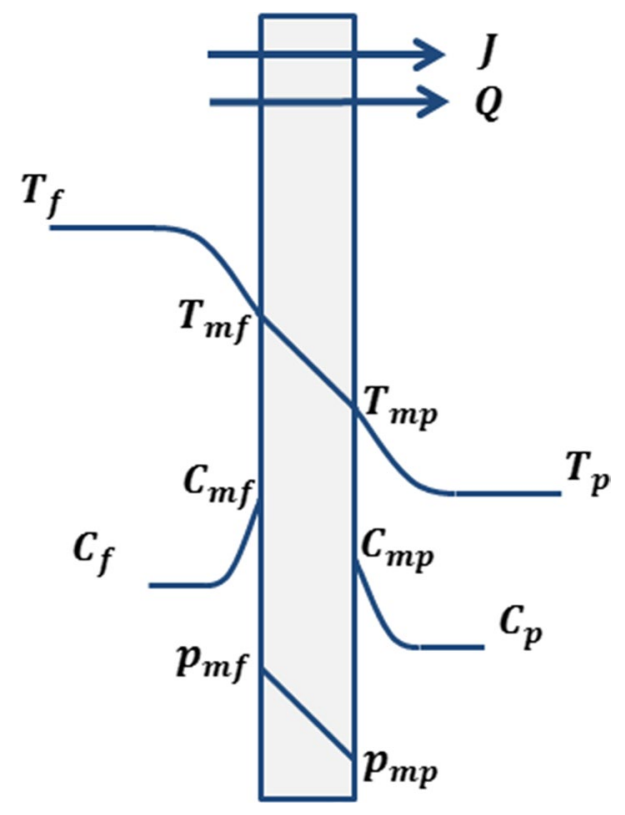

Fig. 2 Temperature concentration and vapour pressure profiles in DCMD. (Adapted from Tomaszewska et al. 1995)

Molecular diffusion $\left(K_{\mathrm{n}}<0.01\right): B_{\mathrm{m}}=\frac{\varepsilon P D M}{\tau \delta R T\left(P_{\mathrm{a}}\right)}$

Transition flow $\left(0.01<K_{\mathrm{n}}<1\right): B_{m}$

$$
=\left(\frac{3 \tau \delta}{2 r \varepsilon}\left(\frac{\pi R T}{8 M}\right)^{0.5}+\frac{\tau \delta R T\left(P_{\mathrm{a}}\right)}{\varepsilon P D M}\right)^{-1}
$$

In Eqs. (2-4) $\varepsilon, \delta, \tau$ and $r$ are the membrane porosity, membrane tortuosity, membrane thickness and pore radius of the membrane, respectively. $\Delta p$ is the vapour pressure difference across the membrane, and $M$ is the molecular mass of the water vapour. $R$ and $T_{\mathrm{m}}$ are the universal gas constant and the average temperature across the membrane, respectively. $P_{\mathrm{a}}$ is the partial pressure of air in the membrane pores, $P$ is the total pressure and $D$ is the diffusion coefficient.

Heat transfer occurs as a result of four mechanisms (Bandini et al. 1991; Kurokawa et al. 1991; Alklaibi and Lior 2006, Andrjesdóttir et al. 2013): (1) convective heat transfer from the concentrated feed to the liquid-vapour interface at the membrane surface, (2) heat conduction through the membrane, (3) latent heat vaporisation and (4) lastly convective heat transfer from the permeate membrane vapour-liquid interface to the permeate. Heat transfer from the concentrated feed to the permeate can expressed in Eqs. (5)-(7):

$Q_{\mathrm{f}}=h_{\mathrm{f}}\left(T_{\mathrm{f}}-T_{\mathrm{mf}}\right)$

$Q_{\mathrm{m}}=\frac{k_{\mathrm{m}}}{\delta}\left(T_{\mathrm{mf}}-T_{\mathrm{mp}}\right)+J H_{\mathrm{v}}$
$Q_{\mathrm{p}}=h_{\mathrm{p}}\left(T_{\mathrm{mp}}-T_{\mathrm{p}}\right)$

where $h_{\mathrm{f}}$ is the feed side heat transfer coefficient and $h_{\mathrm{p}}$ the permeate heat transfer coefficient. These heat transfer coefficients can be calculated from correlation available in the literature (Bouguecha et al. 2003). $k_{m}$ and $H_{v}$ are the thermal conductivity of the membrane and the latent heat of vaporisation, respectively. At steady state:

$Q_{\mathrm{f}}=Q_{\mathrm{p}}=Q_{\mathrm{m}}$

The membrane thermal conductivity $k_{m}$ can be calculated from:

$k_{m}=\varepsilon k_{\text {air }}+k_{s}(1-\varepsilon)$

$k_{\mathrm{s}}$ and $k_{\text {air }}$ are the thermal conductivity of the membrane polymer material and the thermal conductivity of air present in the pores, respectively.

By combining Eqs. (1), (5)-(8) and rearranging, the following expressions for $T_{\mathrm{mf}}$ and $T_{\mathrm{mp}}$ can be obtained (Bouguecha et al. 2003; Ho et al. 2012):

$T_{\mathrm{mf}}=\frac{h_{\mathrm{m}}\left(T_{\mathrm{p}}+T_{\mathrm{f}}\left(\frac{h_{\mathrm{f}}}{h_{\mathrm{p}}}\right)\right)+h_{\mathrm{f}} T_{\mathrm{f}}-J H_{\mathrm{v}}}{h_{\mathrm{m}}+h_{\mathrm{p}}\left(1+\frac{h_{\mathrm{m}}}{h_{\mathrm{p}}}\right)}$

$T_{\mathrm{mf}}=\frac{h_{\mathrm{m}}\left(T_{\mathrm{f}}+T_{\mathrm{p}}\left(\frac{h_{\mathrm{p}}}{h_{\mathrm{f}}}\right)\right)+h_{\mathrm{p}} T_{\mathrm{p}}+J H_{\mathrm{v}}}{h_{\mathrm{m}}+h_{\mathrm{p}}\left(1+\frac{h_{\mathrm{m}}}{h_{\mathrm{f}}}\right)}$

$h_{m}$ is the membrane heat transfer coefficient and is calculated from (Schofield et al. 1987):

$h_{\mathrm{m}}=\frac{\varepsilon k_{\mathrm{air}}+k_{\mathrm{m}}(1-\varepsilon)}{\delta}$

The feed concentration at the membrane surface is given by:

$C_{\mathrm{mf}}=C_{\mathrm{f}} e^{\left(\frac{J}{\rho k_{f}}\right)}$

where $\rho$ is the feed density and $k_{f}$ is the feed mass transfer coefficient

\section{Materials and methodology}

\section{DCMD experimental set-up}

Bench-scale, batch mode experiments were conducted on a custom-built MD system (Fig. 3). The process fluid flowed in counter-current direction to the cooling water 
against the interface of the hollow fibre membrane Microdyn module.

Digital thermocouples (resolution of $0.1{ }^{\circ} \mathrm{C}$ and accuracy of $+1{ }^{\circ} \mathrm{C}$ ) and pressure gauges (range of $0-100 \mathrm{kPa}$ ) were attached to the feed and lumen side of the membrane module, respectively, to monitor the inlet and outlet temperatures and pressures of the respective process fluids. $0.25 \mathrm{~kW}$ peristaltic pumps were used to circulate the heated feed and the cooled condensate and the pickup water (C\&PUW) through the MD module. The water vapour that emitted from the feed side (via the membrane) was condensed, collected and weighed in the C\&PUW tank. Hand-held electrical conductivity meters were used measure the quality of the feed and the C\&PUW.

\section{Membrane characteristics}

The specific membrane properties of the hollow fibre Microdyn membrane module are: membrane material: polypropylene; total interfacial area: $0.1 \mathrm{~m}^{2}$; pore size (nominal): $0.2 \mu \mathrm{m}$; number of membranes: 40 ; porosity: $70 \%$; membrane thickness: $120 \mu \mathrm{m}$; membrane internal diameter: $1.5 \mathrm{~mm}$; membrane external diameter: $2.8 \mathrm{~mm}$.

\section{Experimental conditions}

Experiments were conducted using three feed solutions: synthetic $\mathrm{NaCl}$ solutions, industrial spent ion regenerant brines and industrial RO brines.

\section{Synthetic $\mathrm{NaCl}$ solutions preparation and treatment}

Analytical-grade $\mathrm{NaCl}$ was dissolved in tap water to obtain solutions varying between concentrations of $2.5-10 \mathrm{wt} \%$, respectively These solutions were treated in the DCMD set-up at varying inlet temperatures $\left(18-45^{\circ} \mathrm{C}\right)$, feed flow rates $(32.1-156 \mathrm{l} / \mathrm{h})$ and permeate flow rates $(32.1-111 \mathrm{l} / \mathrm{h})$, respectively.

These solutions were used to establish process conditions for treatment of industrial brines (spent ion exchange regenerant and RO brines).

\section{Industrial spent ion exchange regenerant brines treatment}

Brines produced from the regeneration of spent ion exchange resins, from a local petrochemical company, were experimentally treated at varying temperatures of $20{ }^{\circ} \mathrm{C}, 27^{\circ} \mathrm{C}$, $35{ }^{\circ} \mathrm{C}, 38^{\circ} \mathrm{C}, 40{ }^{\circ} \mathrm{C}$ and $45^{\circ} \mathrm{C}$ in the DCMD set-up. Ion exchange is one of the processes employed for petrochemical

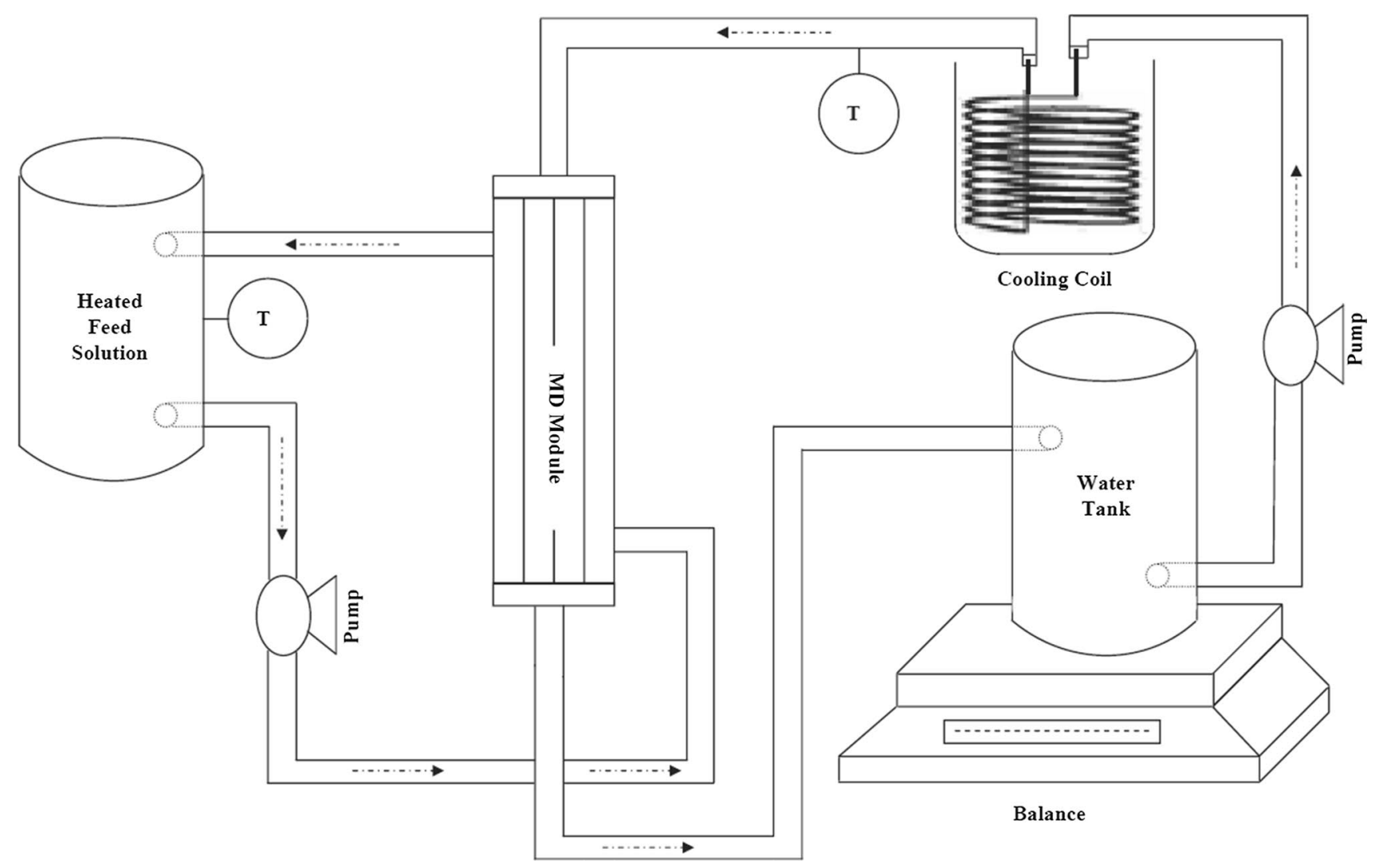

Fig. 3 DCMD experimental set-up (Osman et al. 2010) 
Table 1 Typical composition of the spent ion exchange regenerant brine
Table 2 Typical composition of RO brine from petrochemical process

\begin{tabular}{ll}
\hline Ion & $\begin{array}{l}\text { Concen- } \\
\text { tration/ } \\
\text { value }\end{array}$ \\
\hline $\mathrm{Ca}(\mathrm{mg} / \mathrm{L})$ & 2000 \\
$\mathrm{Mg}(\mathrm{mg} / \mathrm{L})$ & 500 \\
$\mathrm{Na}(\mathrm{mg} / \mathrm{L})$ & 10000 \\
$\mathrm{Cl}(\mathrm{mg} / \mathrm{L})$ & 10000 \\
$\mathrm{Ba}(\mathrm{mg} / \mathrm{L})$ & 0.2 \\
$\mathrm{SO}{ }_{4}(\mathrm{mg} / \mathrm{L})$ & 1500 \\
$\mathrm{~F}(\mathrm{mg} / \mathrm{L})$ & 20 \\
$\mathrm{TOC}(\mathrm{mg} / \mathrm{L})$ & 60 \\
$\mathrm{TDS}(\mathrm{mg} / \mathrm{L})$ & 30000 \\
$\mathrm{pH}$ & 2 \\
\hline
\end{tabular}

\begin{tabular}{ll}
\hline Ion & $\begin{array}{l}\text { Concen- } \\
\text { tration/ } \\
\text { value }\end{array}$ \\
\hline $\mathrm{Ca}(\mathrm{mg} / \mathrm{L})$ & 400 \\
$\mathrm{Na}(\mathrm{mg} / \mathrm{L})$ & 900 \\
$\mathrm{Cl}(\mathrm{mg} / \mathrm{L})$ & 800 \\
$\mathrm{Ba},(\mathrm{mg} / \mathrm{L})$ & 0.2 \\
$\mathrm{SO}_{4}(\mathrm{mg} / \mathrm{L})$ & 3200 \\
$\mathrm{~F}(\mathrm{mg} / \mathrm{L})$ & 20 \\
$\mathrm{TOC}(\mathrm{mg} / \mathrm{L})$ & 60 \\
$\mathrm{TDS}(\mathrm{mg} / \mathrm{L})$ & 30,000 \\
$\mathrm{pH}$ & $5-6$ \\
\hline
\end{tabular}

and chemical operations. The typical concentrations from the resultant spent ion exchange regenerant are shown in Table 1.

\section{Industrial RO brines treatment and characterisation}

During petrochemical and chemical operations, process effluents are generated which are pre-treated and thereafter treated in a reverse osmosis plant for water and salt recovery. RO brines are generated which require further processing. The RO brines were experimentally treated in the DCMD set-up at varying temperatures of $20^{\circ} \mathrm{C}, 27^{\circ} \mathrm{C}, 35^{\circ} \mathrm{C}, 38^{\circ} \mathrm{C}$, $40{ }^{\circ} \mathrm{C}$ and $45^{\circ} \mathrm{C}$. The typical concentrations of the major ions and organics are tabulated in Table 2.

\section{Characterisation of RO precipitants}

The RO precipitate samples were prepared according to the standardised PANalytical backloading system, which provides nearly random distribution of the particles. The sample were analysed using a PANalytical X'Pert Pro powder diffractometer in $\theta-\theta$ configuration with an X'Celerator detector and variable divergence and fixed receiving slits with
Fe filtered Co-K $\alpha$ radiation $(\lambda=1.789 \AA)$. The phases were identified using X'Pert Highscore plus software. The relative phase amounts (wt\%) were estimated using the Rietveld method (Autoquan Program). Errors are on the three-sigma level in the column to the right of the amount.

\section{DCMD mathematical modelling algorithm}

A mathematical model was developed to compare the experimental data to the Knudsen diffusion, molecular diffusion and transition predictive models. The system of nonlinear equations, describing the DCMD mass and heat transfer, was iteratively solved in MATLAB ${ }^{\circledR}$. A computational algorithm (Fig. 4) was used to iteratively solve the equations. The mathematical model was developed based on the following assumptions:

- The DCMD system is at steady state.

- Flow occurs in one dimension only.

- Only water vapour is transported through membrane pores.

- The air and water vapour in the pores are at equilibrium.

- There is no heat loss to the surroundings. Heat transfer occurs only in the DCMD system.

- Pressure drop across the DCMD system is negligible.

\section{Results and discussion}

\section{Treatment of synthetic $\mathrm{NaCl}$ solutions using MD}

Results from the synthetic $\mathrm{NaCl}$ solution tests are tabulated in Table 3. These results show that an increase in the feed inlet temperature increases the permeate flux, while an increase in feed concentration decreased the permeate flux and resulted in a decrease in temperature polarisation effects. An increase in the feed and permeate flow rates, respectively, increases the permeate flux, but to a smaller degree than for an increase in the feed temperature (Table 3). These results are in conformance with that found in the literature ( $\mathrm{Ji}$ et al. 2010; Bush et al. 2016).

\section{Treatment of spent ion exchange regenerant brine using DCMD}

Spent ion exchange regenerant experimental runs were performed, and the permeate/condensate flux and water recovery were plotted as a function of time (Fig. 5). The initial condensate flux was $0.9 \mathrm{~L} \mathrm{~m}^{-2} \mathrm{~h}^{-1}$ which declined to $0.56 \mathrm{~L} \mathrm{~m}^{-2} \mathrm{~h}^{-1}$ after the end of the experimental run after $26 \mathrm{~h}$. A steeper decline in flux was observed after $18 \mathrm{~h}$ as a result of possible concentration polarisation 
Fig. 4 Computational algorithm to numerically solve the mass and heat transfer in DCMD
Assign membrane characteristics and operating parameters of the system

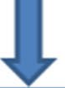

Set $T_{m f}($ initial $)=T_{f} ; T_{m p}($ initial $)=T_{p} ; C_{m f}($ initial $)=C_{f}$ L

Calculate vapour pressures

$p_{m f}$ and $p_{m p}$ from the

Antoine equation and

Rauolt's law

Calculate $J$ from

equations $2 / 3 / 4$

Calculate $h_{f}$ and $h_{p}$. Calculate $h_{m}$ from equation 12

Calculate new $T_{m f}$ (new), $T_{m p}$ (new) and $C_{m f}$ (new) equations 10, 11 and 13

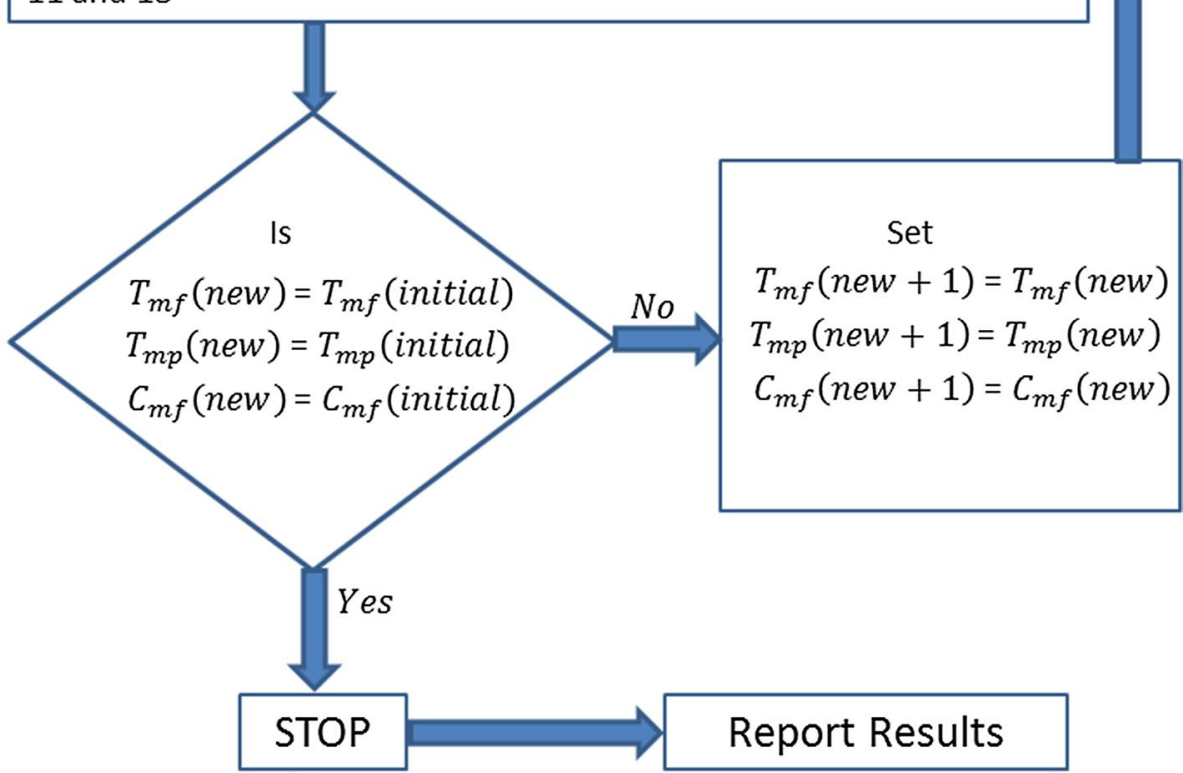

Table 3 Effect of operating parameters on the membrane flux Effect of increasing:

Membrane flux

Feed inlet temperature $\uparrow$

Feed inlet concentration

Feed flow rate

Permeate flow rate

$\uparrow$ denotes an increase, and $\downarrow$ denotes a decrease

caused by potential salt precipitation. A water recovery of $68 \%$ at the end of the run was obtained and a final permeate of $131.4 \mu \mathrm{S} / \mathrm{cm}$

\section{Treatment of RO brines using DCMD}

Triplicate experimental runs were performed, and the permeate/condensate flux was plotted as a function of time (Fig. 6). The flux gradually decreased with time from 1.3 LMH to $0.7 \mathrm{LMH}$ after $21.5 \mathrm{~h}$ as a result of concentration polarisation and fouling/scaling build-up on the membrane surface. A steeper flux decline is also visible after $17 \mathrm{~h}$ as a result of salt precipitation that was observed in the feed tank. These salt crystals were shown by XRD analysis (Fig. 7) to be calcium sulphate dihydrate. Water recoveries at the end of the runs were $70 \%$ at a final permeate of $120.3 \mu \mathrm{S} / \mathrm{cm}$ 
Fig. 5 Condensate (permeate) flux and water recovery as a function of time $\left(T_{\mathrm{f}}=34{ }^{\circ} \mathrm{C}\right.$; $T_{\mathrm{p}}=11^{\circ} \mathrm{C} ; q_{\mathrm{f}}=80 \mathrm{l} / \mathrm{h}$; $\left.q_{\mathrm{p}}=32 \mathrm{l} / \mathrm{h}\right)$

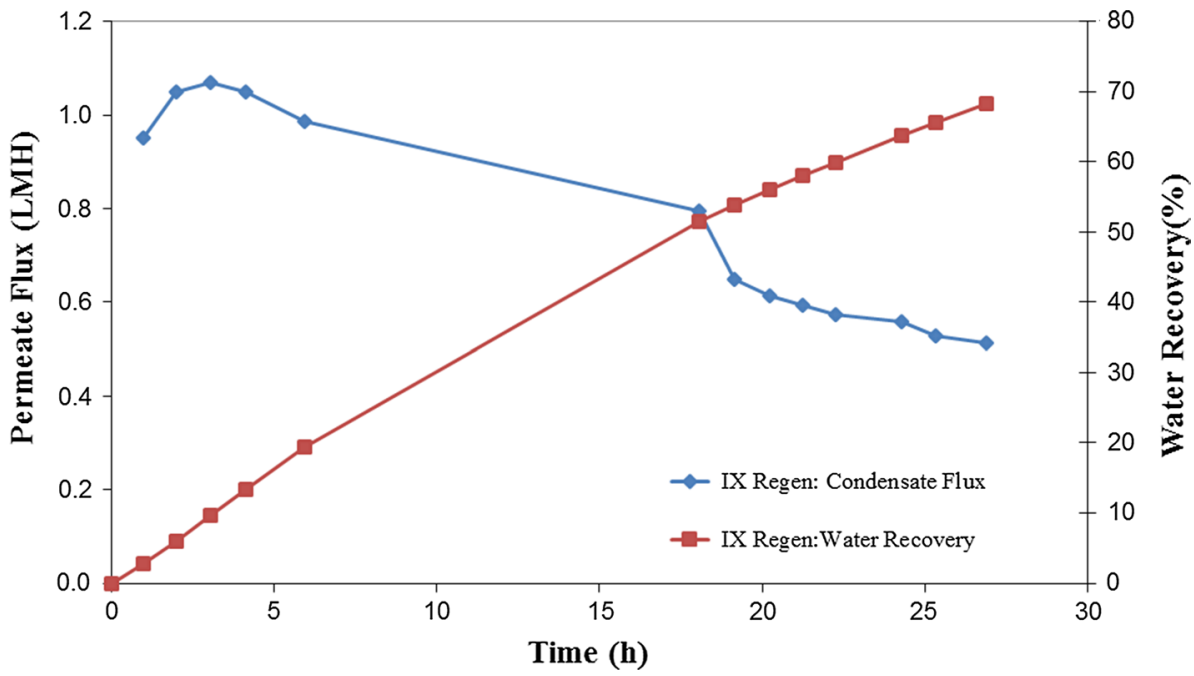

\section{Computational modelling and comparison of experimental results}

Further experimental studies on the synthetic $\mathrm{NaCl}$ solution, industrial spent ion exchange regenerant and $\mathrm{RO}$ brines were conducted at inlet feed temperatures of $20^{\circ} \mathrm{C}, 27^{\circ} \mathrm{C}, 35^{\circ} \mathrm{C}$, $38^{\circ} \mathrm{C}, 40{ }^{\circ} \mathrm{C}$ and $45^{\circ} \mathrm{C}$, respectively. The inlet permeate temperature was maintained at $10^{\circ} \mathrm{C}$, the feed flow rate and permeate flow rate were $80 \mathrm{l} / \mathrm{h}$ and $32 \mathrm{l} / \mathrm{h}$, respectively.

\section{Synthetic $\mathrm{NaCl}$ solutions}

The results for the experimental runs for the synthetic $\mathrm{NaCl}$ solution $(2.5 \% \mathrm{wt})$ were compared to the well-known predictive models as shown in Fig. 8. The Knudsen theoretical model best predicted the performance of the membrane with a mean absolute percentage error (MAPE) of $7.9 \%$. The MAPE when compared to the transition flow model was $20.5 \%$.

Fig. 6 Permeate flux as a function of time $\left(T_{\mathrm{f}}=34{ }^{\circ} \mathrm{C}\right.$; $T_{\mathrm{p}}=12{ }^{\circ} \mathrm{C} ; q_{\mathrm{f}}=1330 \mathrm{ml} / \mathrm{min}$; $q_{\mathrm{p}}=535 \mathrm{ml} / \mathrm{min}$ )

\section{Industrial spent ion exchange regenerant}

The results for the experimental runs for the spent ion exchange regenerant were plotted and compared to the well-known predictive models as shown in Figs. 9 and 10. For the Knudsen diffusion theoretical model, a mean absolute percentage error (MAPE) of $21 \%$ was obtained. The MAPE for the transition flow model was found to $13.3 \%$. Hence, for spent ion exchange regenerant the transition flow model was best predicts the membrane performance.

\section{Industrial RO brine}

The results from these experimental runs for the RO brine solutions were plotted and compared to the well-known predictive models as shown in Fig. 11 and Fig. 12. The Knudsen diffusion theoretical model best predicted the performance of the membrane with a mean absolute percentage error (MAPE) of $10.5 \%$ for the industrial RO brine. When

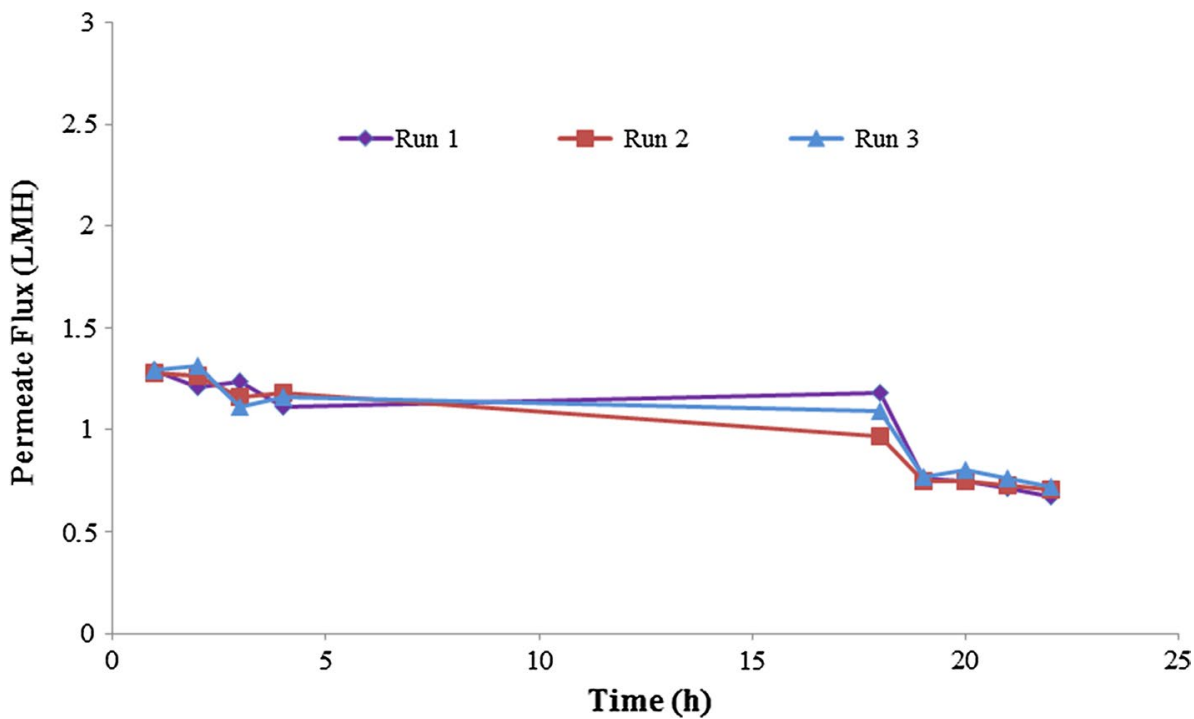




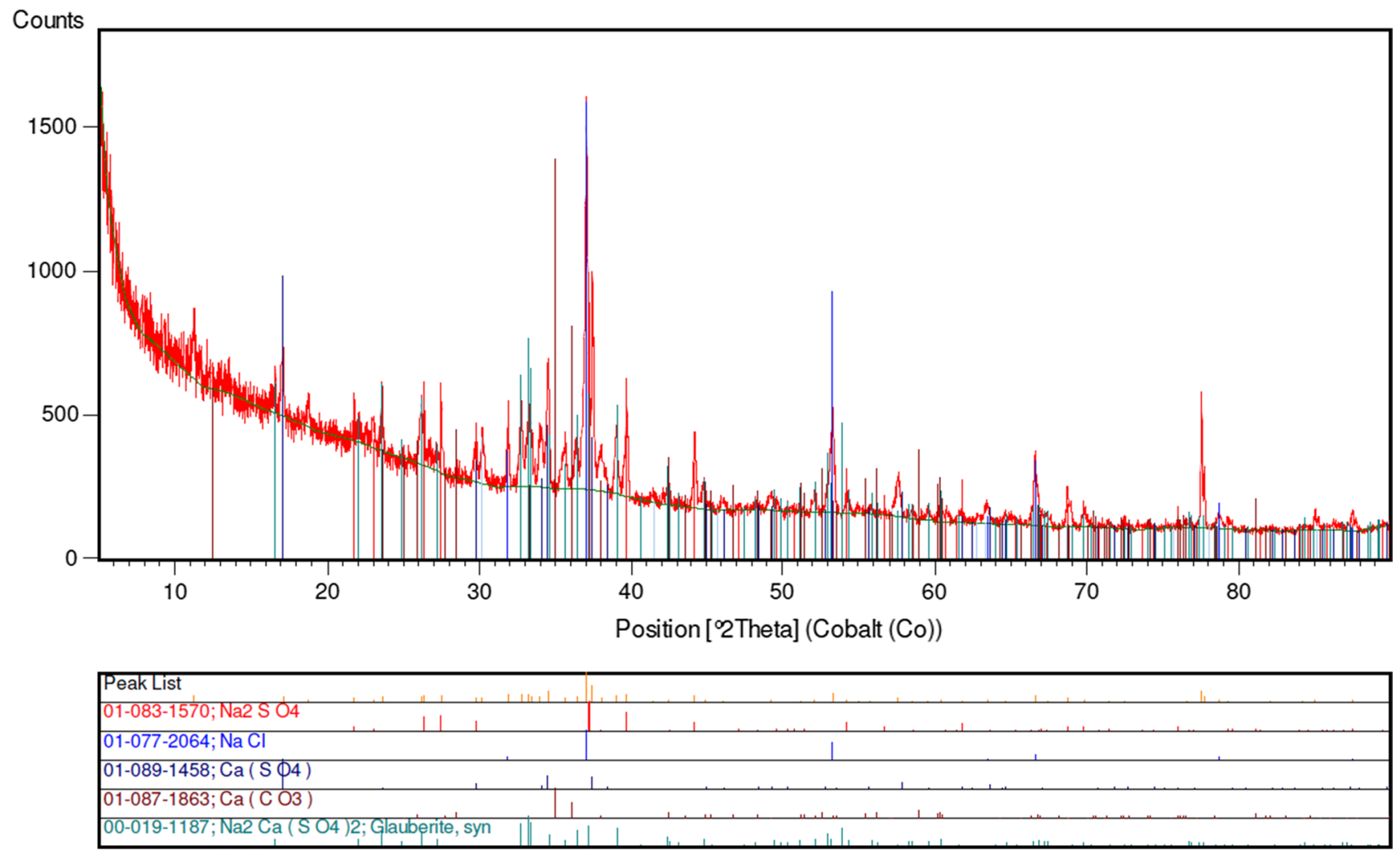

Fig. 7 XRD analysis of the crystals produced from the desalination of RO brine

Fig. 8 Knudsen theoretical model best fitted the membrane performance of the synthetic $\mathrm{NaCl}$ solution

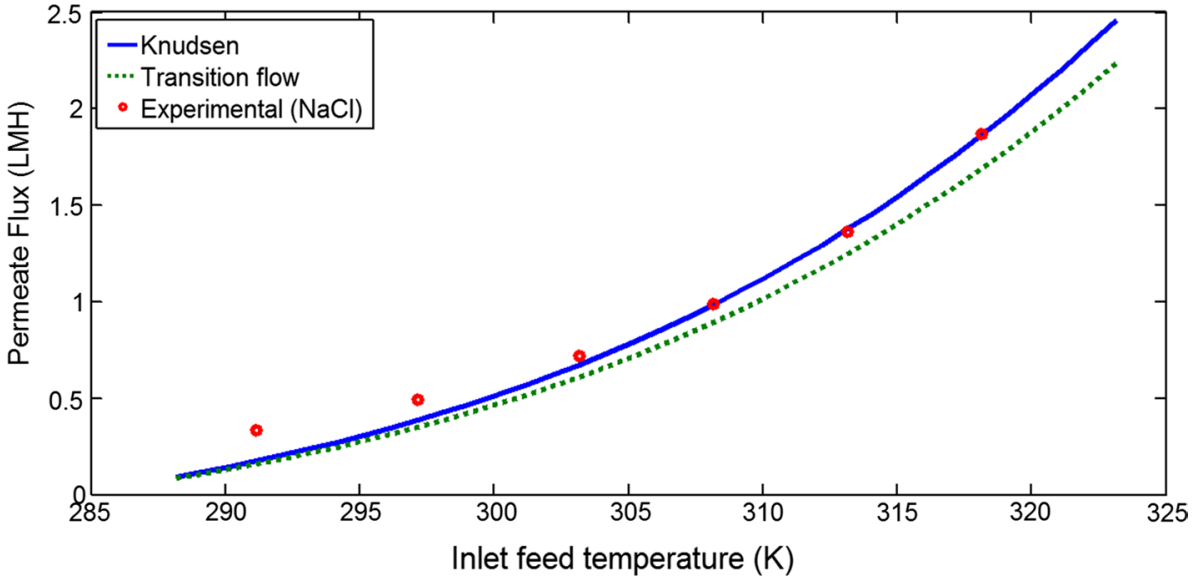

compared to the transition model, the MAPE was found to be $22 \%$

\section{Conclusions}

In this study, the direct contact membrane distillation (DCMD) process successfully treated spent ion exchange regenerant and RO brines obtained from a petrochemical factory. The experimental results obtained were compared to the classical well-known Knudsen, molecular diffusion and transition predictive models, which were coded in MATLAB. For the spent ion exchange regenerant, a salt rejection of $99.7 \%$, a water recovery of $68 \%$ and a C\&PUW water quality of $131.4 \mu \mathrm{S} / \mathrm{cm}$ were obtained. For the RO brines salt rejections, water recoveries and pickup water conductivities were $70 \%, 99.7 \%$ and $120.3 \mu \mathrm{S} / \mathrm{cm}$, respectively. The Knudsen model best predicted the performance of the 
Fig. 9 A comparison between the Knudsen model and experimental results for spent ion exchange regenerant
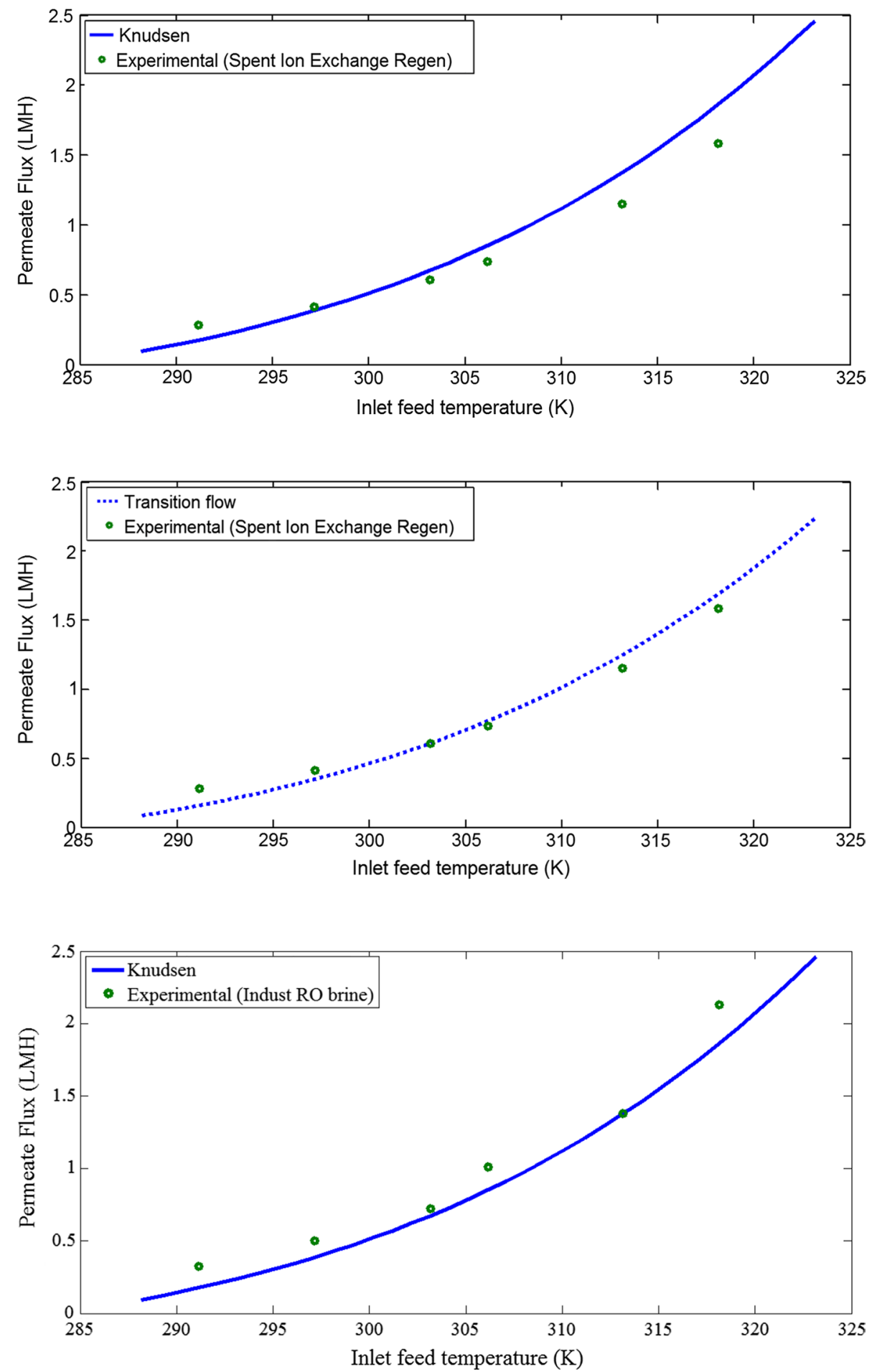

Fig. 10 A comparison between the transition flow model and experimental results for spent ion exchange regenerant
Fig. 11 Knudsen diffusion theoretical model best predicted the membrane performance of the industrial RO brine brine had a MAPE of $10.5 \%$ when compared to the Knudsen model. This study shows that predictive modelling can provide useful insight into the process design and up-scaling of DCMD systems for industrial effluent and brine treatment. for the industrial spent ion exchange regenerant brine with a mean absolute percentage error (MAPE) of $13.3 \%$. The RO 
Fig. 12 A comparison between the transition flow model and experimental results for the industrial $\mathrm{RO}$ brine

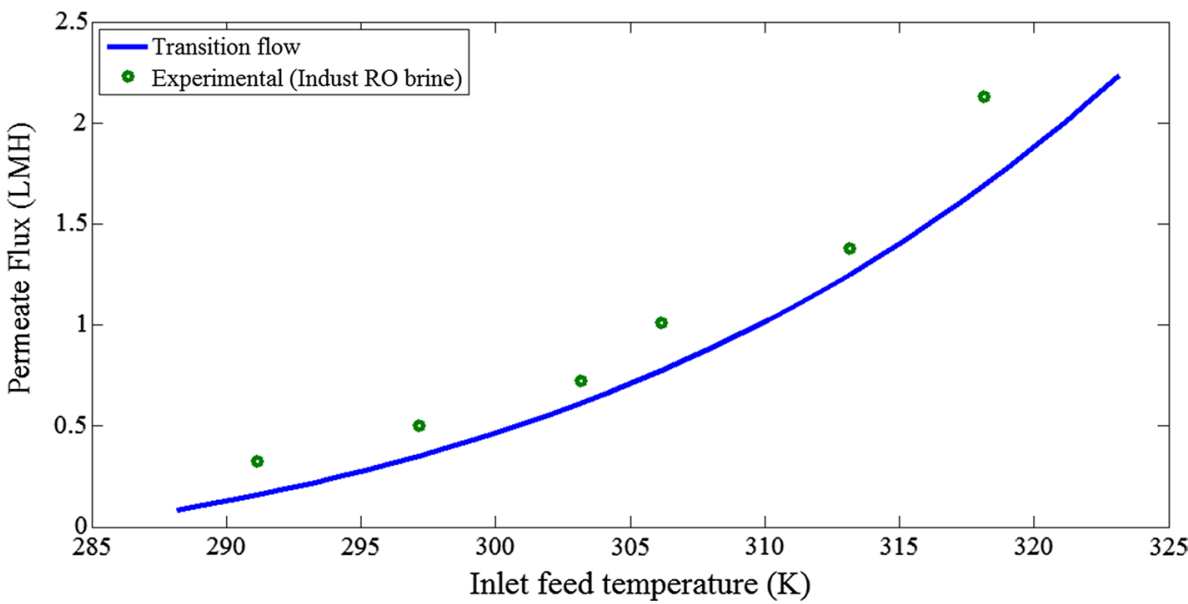

Acknowledgements The authors acknowledge the support and funding received from the Council for Scientific and Industrial Research (CSIR) to complete this research project.

Open Access This article is distributed under the terms of the Creative Commons Attribution 4.0 International License (http://creativeco mmons.org/licenses/by/4.0/), which permits unrestricted use, distribution, and reproduction in any medium, provided you give appropriate credit to the original author(s) and the source, provide a link to the Creative Commons license, and indicate if changes were made.

\section{References}

Abdulgader HA, Kochkodan V, Hilal N (2013) Hybrid ion exchangepressure driven membrane processes in water treatment: a review. Sep Purif Technol 116:253-264

Abu-Zeid MAER, Zhang Y, Dong H, Zhang L, Chen HL, Hou L (2015) A comprehensive review of vacuum membrane distillation technique. Desalination 356:1-14

Adham S, Hussain A, Matar JM, Dores R, Janson A (2013) Application of membrane distillation for desalting brines from thermal desalination plants. Desalination 314:101-108

Ahmad HM, Khalifa AE, Antar MA (2015) Water desalination using direct contact membrane distillation system. In: ASME international mechanical engineering congress and exposition, proceedings (IMECE)

Alhathal Al-Anezi A, Sharif AO, Sanduk MI, Khan AR (2013) Potential of membrane distillation-a comprehensive review. Int J Water $7: 317-346$

Alkhudhiri A, Darwish N, Hilal N (2012) Membrane distillation: a comprehensive review. Desalination 287:2-18

Alklaibi AM, Lior N (2006) Heat and mass transfer resistance analysis of membrane distillation. J Membr Sci 282:362-369

Alshahri F (2017) Heavy metal contamination in sand and sediments near to disposal site of reject brine from desalination plant, Arabian Gulf: assessment of environmental pollution. Environ Sci Pollut Res 24:1821-1831

Andrjesdóttir Ó, Ong CL, Nabavi M, Paredes S, Khalil ASG, Michel B, Poulikakos D (2013) An experimentally optimized model for heat and mass transfer in direct contact membrane distillation. Int J Heat Mass Transf 66:855-867

Ashoor BB, Mansour S, Giwa A, Dufour V, Hasan SW (2016) Principles and applications of direct contact membrane distillation (DCMD): a comprehensive review. Desalination 398:222-246
Awad M, Janajreh I, Fath H (2013) Low energy direct contact membrane distillation: towards optimal flow configuration. In: Proceedings of 2013 international renewable and sustainable energy conference (IRSEC) 2013, pp 471-476

Bagger-Jørgensen R, Meyer AS, Pinelo M, Varming C, Jonsson G (2011) Recovery of volatile fruit juice aroma compounds by membrane technology: sweeping gas versus vacuum membrane distillation. Innov Food Sci Emerg Technol 12:388-397

Bandini S, Gostoli C, Sarti GC (1991) Role of heat and mass transfer in membrane distillation process. In: Institution of chemical engineers symposium series, pp 91-106

Battaerd HAJ, Blesing NV, Bolto BA, Cope AFG, Stephens GK, Weiss DE, Willis D, Worboys JC (1973) An ion-exchange process with thermal regeneration VIII. Preliminary pilot plant results for the partial demineralisation of brackish waters. Desalination $12: 217-237$

Bélafi-Bakó K, Boór A (2011) Concentration of Cornelian cherry fruit juice by membrane osmotic distillation. Desalination Water Treat $35: 271-274$

Bigham S, Kouhikamali R, Zadeh MP (2015) A general guide to design of falling film evaporators utilized in multi effect desalination units operating at high vapor qualities under a sub-atmospheric condition. Energy 84:279-288

Bogler A, Lin S, Bar-Zeev E (2017) Biofouling of membrane distillation, forward osmosis and pressure retarded osmosis: principles, impacts and future directions. J Membr Sci 542:378-398

Bouguecha S, Chouikh R, Dhahbi M (2003) Numerical study of the coupled heat and mass transfer in membrane distillation. Desalination 152:245-252

Burgoyne A, Vahdati MM (2000) Direct contact membrane distillation. Sep Sci Technol 35:1257-1284

Bush JA, Vanneste J, Cath TY (2016) Membrane distillation for concentration of hypersaline brines from the Great Salt Lake: effects of scaling and fouling on performance, efficiency, and salt rejection. Sep Purif Technol 170:78-91

Chafidz A, Kerme ED, Wazeer I, Khalid Y, Ajbar A, Al-Zahrani SM (2016) Design and fabrication of a portable and hybrid solarpowered membrane distillation system. J Clean Prod 133:631-647

Chang H, Lyu SG, Tsai CM, Chen YH, Cheng TW, Chou YH (2012) Experimental and simulation study of a solar thermal driven membrane distillation desalination process. Desalination 286:400-411

Drioli E, Ali A, Macedonio F (2015) Membrane distillation: recent developments and perspectives. Desalination 356:56-84

El-Bourawi MS, Ding Z, Ma R, Khayet M (2006) A framework for better understanding membrane distillation separation process. $\mathrm{J}$ Membr Sci 285:4-29 
Eykens L, De Sitter K, Dotremont C, Pinoy L, Van Der Bruggen B (2017) Membrane synthesis for membrane distillation: a review. Sep Purif Technol 182:36-51

Fatehi L, Kargari A, Bastani D, Soleimani M, Shirazi MMA (2017) Saline brine desalination: application of sweeping gas membrane distillation (SGMD). Desalination Water Treat 71:12-18

Gryta M, Tomaszewska M, Karakulski K (2006) Wastewater treatment by membrane distillation. Desalination 198:67-73

Gullinkala T, Digman B, Gorey C, Hausman R, Escobar IC (2010) Chpater 4 desalination: reverse osmosis and membrane distillation. Sustain Sci Eng 2:65-93

Guo Z, Zhang XM, Luan JY, Peng HZ (2017) Research advances in air-gap membrane distillation technology. Xiandai Huagong/Mod Chem Ind 37:16-19, 21

Gurreri L, Tamburini A, Cipollina A, Micale G, Ciofalo M (2017) Performance comparison between overlapped and woven spacers for membrane distillation. Desalination Water Treat 69:178-189

Hendry BA (1982) Continuous countercurrent ion exchange for desalination and tertiary treatment of effluents and other brackish waters. Water Sci Technol 14:535-552

Ho CD, Yang TJ, Wang BC (2012) Modeling of conjugated heat transfer in direct-contact membrane distillation of seawater desalination systems. Chem Eng Technol 35:1765-1776

Hossack BR, Puglis HJ, Battaglin WA, Anderson CW, Honeycutt RK, Smalling KL (2017) Widespread legacy brine contamination from oil production reduces survival of chorus frog larvae. Environ Pollut 231:742-751

Ji X, Curcio E, Al Obaidani S, Di Profio G, Fontananova E, Drioli E (2010) Membrane distillation-crystallization of seawater reverse osmosis brines. Sep Purif Technol 71:76-82

Joe Patrick Gnanaraj S, Ramachandran S, Logesh K (2016) A review on solar water distillation using thermal energy storage. Res $\mathrm{J}$ Pharm Biol Chem Sci 7:2471-2477

Kaplan R, Mamrosh D, Salih HH, Dastgheib SA (2017) Assessment of desalination technologies for treatment of a highly saline brine from a potential $\mathrm{CO}<\inf >2</ \mathrm{inf}>$ storage site. Desalination 404:87-101

Kesieme UK, Aral H (2015) Application of membrane distillation and solvent extraction for water and acid recovery from acidic mining waste and process solutions. J Environ Chem Eng 3:2050-2056

Khayet M, Godino MP, Mengual JI (2003) Possibility of nuclear desalination through various membrane distillation configurations: a comparative study. Int J Nucl Desaliniation 1:30-46

Khayet M, Mengual JI, Zakrzewska-Trznadel G (2005) Direct contact membrane distillation for nuclear desalination. Part I: review of membranes used in membrane distillation and methods for their characterisation. Int J Nucl Desaliniation 1:435-449

Kim AS, Lee HS, Moon DS, Kim HJ (2017) Self-adjusting, combined diffusion in direct contact and vacuum membrane distillation. J Membr Sci 543:255-268

Kurokawa H, Sawa T, Mitani K (1991) Characteristics of heat and mass transfer in direct-contact membrane distillation. Kagaku Kogaku Ronbunshu 17:1168-1174

Lawson KW, Lloyd DR (1997) Membrane distillation. J Membr Sci 124:1-25

Lee JG, Kim YD, Shim SM, Im BG, Kim WS (2015) Numerical study of a hybrid multi-stage vacuum membrane distillation and pressure-retarded osmosis system. Desalination 363:82-91

Li XM, Zhao B, Wang Z, Xie M, Song J, Nghiem LD, He T, Yang C, Li C, Chen G (2014) Water reclamation from shale gas drilling flow-back fluid using a novel forward osmosis-vacuum membrane distillation hybrid system. Water Sci Technol 69:1036-1044

Luo A, Lior N (2016) Critical review of membrane distillation performance criteria. Desalination Water Treat 57:20093-20140

Mariah L, Buckley CA, Brouckaert CJ, Curcio E, Drioli E, Jaganyi D, Ramjugernath D (2006) Membrane distillation of concentrated brines-role of water activities in the evaluation of driving force. J Membr Sci 280:937-947

Naidu G, Jeong S, Vigneswaran S, Hwang TM, Choi YJ, Kim SH (2016) A review on fouling of membrane distillation. Desalination Water Treat 57:10052-10076

Onsekizoglu Bagci P (2015) Potential of membrane distillation for production of high quality fruit juice concentrate. Crit Rev Food Sci Nutr 55:1096-1111

Osman MS, Schoeman JJ, Baratta LM (2010) Desalination/concentration of reverse osmosis and electrodialysis brines with membrane distillation. Desalination Water Treat 24:293-301

Pangarkar BL, Sane MG, Parjane SB, Guddad M (2013) Status of membrane distillation for water and wastewater treatment-A review. Desalination Water Treat 52:5199-5218

Phattaranawik J, Jiraratananon R, Fane AG (2003) Effect of pore size distribution and air flux on mass transport in direct contact membrane distillation. J Membr Sci 215:75-85

Pless JD, Philips MLF, Voigt JA, Moore D, Axness M, Krumhans JL, Nenoff TM (2006) Desalination of brackish waters using ionexchange media. Ind Eng Chem Res 45:4752-4756

Sarkar S, Sengupta AK (2007) Hybrid ion exchange/nanofiltration (HIX-NF) process for energy efficient desalination of brackish and seawater. In: AIChE annual meeting, conference proceedings

Schofield RW, Fane AG, Fell CJD (1987) Heat and mass transfer in membrane distillation. J Membr Sci 33:299-313

Smith RC, Sengupta AK (2015) Integrating tunable anion exchange with reverse osmosis for enhanced recovery during inland brackish water desalination. Environ Sci Technol 49:5637-5644

Soliman MF, Abdel-Aziz MH, Bamaga OA, Gzara L, Al-Sharif SF, Bassyouni M, Rehan ZA, Drioli E, Albeirutty M, Ahmed I, Ali I, Bake H (2017) Performance evaluation of blended PVDF membranes for desalination of seawater RO brine using direct contact membrane distillation. Desalination Water Treat 63:6-14

Swaminathan J, Chung HW, Warsinger DM, Lienhard VJH (2016) Membrane distillation model based on heat exchanger theory and configuration comparison. Appl Energy 184:491-505

Thomas N, Mavukkandy MO, Loutatidou S, Arafat HA (2017) Membrane distillation research \& implementation: lessons from the past five decades. Sep Purif Technol 189:108-127

Tijing LD, Choi JS, Lee S, Kim SH, Shon HK (2014) Recent progress of membrane distillation using electrospun nanofibrous membrane. J Membr Sci 453:435-462

Tomaszewska M, Gryta M, Morawski AW (1995) Erratum to "A study of separation by the direct-contact membrane distillation process" Sep. Technol. 4 (1994) 244 (PII:0956-9618(94)80028-6). Sep Technol 5:57

Wang P, Chung TS (2015) Recent advances in membrane distillation processes: membrane development, configuration design and application exploring. J Membr Sci 474:39-56

Xie M, Nghiem LD, Price WE, Elimelech M (2013) A forward osmosis-membrane distillation hybrid process for direct sewer mining: system performance and limitations. Environ Sci Technol 47:13486-13493

Yang S, Jeong YS, Cho SP, Han C (2013) Vacuum membrane distillation of CO2-rich alkanolamines. Separations division 2013core programming area at the $2013 \mathrm{AIChE}$ annual meeting: global challenges for engineering a sustainable future, 2013, pp 112-113

Zhao ZP, Xu L, Shang X, Chen K (2013) Water regeneration from human urine by vacuum membrane distillation and analysis of membrane fouling characteristics. Sep Purif Technol 118:369-376

Publisher's Note Springer Nature remains neutral with regard to jurisdictional claims in published maps and institutional affiliations. 